Article

\title{
Feasibility of Using Electrodes with Ultralow Pt Loading in Two-Chamber Microbial Electrolysis Cells
}

\author{
Eunjin Jwa ${ }^{1,+}$, Mijin Kim ${ }^{2,+}$, Ji-Hyung Han ${ }^{1}$, Namjo Jeong ${ }^{1}$, Hyun-Chul Kim ${ }^{3} \mathbb{D}$, Yeo-Myeong Yun ${ }^{4}$ \\ and Joo-Youn $\mathrm{Nam}^{1, *(1)}$
}

check for updates

Citation: Jwa, E.; Kim, M.; Han, J.-H.; Jeong, N.; Kim, H.-C.; Yun, Y.-M.; Nam, J.-Y. Feasibility of Using Electrodes with Ultralow Pt Loading in Two-Chamber Microbial Electrolysis Cells. Energies 2021, 14, 7752. https://doi.org/10.3390/ en14227752

\section{Academic Editors: Michael}

Lienemann, Marika Kokko and Jörg S. Deutzmann

Received: 12 October 2021

Accepted: 13 November 2021

Published: 18 November 2021

Publisher's Note: MDPI stays neutral with regard to jurisdictional claims in published maps and institutional affiliations.

Copyright: (c) 2021 by the authors. Licensee MDPI, Basel, Switzerland. This article is an open access article distributed under the terms and conditions of the Creative Commons Attribution (CC BY) license (https:/ / creativecommons.org/licenses/by/ $4.0 /)$.
1 Marine Energy Convergence and Integration Research Team, Jeju Global Research Center, Korea Institute of Energy Research, 200 Haemajihaean-ro, Gujwa-eup, Jeju 63357, Korea; jej1208@kier.re.kr (E.J.); jihyung0760@kier.re.kr (J.-H.H.); njjeong@kier.re.kr (N.J.)

2 Jeju Groundwater Research Center, Jeju Research Institute, 253, Ayron-ro, Jeju 63147, Korea; mj1561@jri.re.kr

3 Research Institute for Advanced Industrial Technology, College of Science and Technology, Korea University, Sejong 30019, Korea; animaplus@hanmail.net

4 Department of Environmental Engineering, Chungbuk National University, 1 Chungdae-ro, Seowon-gu, Cheongju 28544, Korea; ymyun@cbnu.ac.kr

* Correspondence: jynam@kier.re.kr

+ Both authors contributed to this work equally.

\begin{abstract}
Decreasing the Pt loading and surface area of the cathode was found to accelerate the hydrogen evolution reaction in microbial electrolysis cells (MEC) at low substrate concentrations. The experimental wire cathode used in this study had a reduced Pt loading of $20 \mu \mathrm{g} \mathrm{Pt} / \mathrm{cm}^{2}$ and only $14 \%$ of the surface area of the control disk-type cathode. With the wire cathodes, peak current densities of $33.1 \pm 2.3 \mathrm{~A} / \mathrm{m}^{2}$ to $30.4 \pm 0.5 \mathrm{~A} / \mathrm{m}^{2}$ were obtained at substrate concentrations of $0.4 \mathrm{~g} / \mathrm{L}$ and $1.0 \mathrm{~g} / \mathrm{L}$, respectively, which were 5.4 to 6.2 times higher than those obtained with the disk electrode (5.1-5.7 A $\left./ \mathrm{m}^{2}\right)$. The higher cathode overpotentials and higher current densities obtained with the wire electrode compared to those observed with the disk electrode were advantageous for hydrogen recovery, energy recovery efficiencies, and the hydrogen volume produced $(8.5 \pm 1.2 \mathrm{~mL}$ at $0.4 \mathrm{~g} / \mathrm{L}$ to $23.0 \pm 2.2 \mathrm{~mL}$ at $1.0 \mathrm{~g} / \mathrm{L}$ with the wire electrode; $6.8 \pm 0.4 \mathrm{~mL}$ at $0.4 \mathrm{~g} / \mathrm{L}$ to $21.8 \pm 2.2 \mathrm{~mL}$ at $1.0 \mathrm{~g} / \mathrm{L}$ with the disk electrode). Therefore, the wire electrode, which used only $0.6 \%$ of the Pt catalyst amount in typical disk-type electrodes $\left(0.5 \mathrm{mg} \mathrm{Pt} / \mathrm{cm}^{2}\right)$, was effective at various substrate concentrations. The results of this study are very promising because the capital cost of the MEC reactors can be greatly reduced if the wire-type electrodes with ultralow Pt loading are utilized in field applications.
\end{abstract}

Keywords: cathode; electrode size; energy recovery; hydrogen production; microbial electrolysis cell; Pt loading

\section{Introduction}

The microbial electrolysis cell (MEC) is a novel technology that converts organic matter into waste and wastewater into hydrogen gas [1,2]. In MECs, electrochemically active bacteria in the anode chamber oxidize various substrates, such as domestic wastewater, sewage sludge, dairy wastewater, etc., producing a current in the process [3,4]. The current is then passed to the cathode, where hydrogen gas is generated under the influence of external power. While separators such as ion exchange membranes (anion exchange membrane (AEM) and cation exchange membrane (CEM)), bipolar membranes, and porous membranes are typically used between the cathode and anode in typical two-chamber MECs, membrane-less single-chamber MECs exhibit superior hydrogen production rates and yields in comparison, owing to low internal resistance [5]. However, single-chamber MECs are very challenging to control because the hydrogen generated at the cathode may follow various reaction pathways and convert into low-value products, becoming detrimental to the overall MEC performance [6,7]. Therefore, the presence of a separator 
between the electrodes becomes inevitable and could cause potential losses, which need to be minimized [8].

Another important challenge in the study of MECs is the design of cathodes and suitable catalysts for hydrogen generation. While cathode overpotential can be effectively decreased using a Pt-based cathode owing to low activation overpotential, the high costs associated with Pt tend to increase the overall capital cost of the MEC. Therefore, large surface area non-Pt cathodes that exhibit high current densities, as well as some alternatives to Pt catalysts, such as nickel foam, stainless steel, and molybdenum disulfide, have been successfully examined [9-13]. However, in some of these studies, the significantly larger cathode size relative to the anode surface area was detrimental to hydrogen production in MECs, since large area cathodes appear to provide conducive conditions for methanogens to thrive, leading to the loss of hydrogen $[14,15]$. In addition, most MEC studies use high concentrations of organic substances as fuel, which may not be representative of domestic wastewater conditions [4].

In view of the above considerations, small area cathodes with ultralow Pt loading, which would have competitive pricing compared to conventional Pt cathodes, might be preferable to bulky non-Pt cathodes with all their associated disadvantages as outlined above. It is also known that high overpotentials, although undesirable, are inevitable at the high current density conditions required for efficient hydrogen production. Pt cathodes can be used to reduce the high overpotentials but have high capital costs, as outlined previously, causing a dilemma [16]. Therefore, in this study, we tested a small area cathode (14\% of the surface area of the control electrode) with very low Pt loading $\left(20 \mu \mathrm{g} \mathrm{Pt} / \mathrm{cm}^{2}\right)$ and a low chemical oxygen demand (COD) substrate in two-chamber MECs.

\section{Materials and Methods}

\subsection{Reactor Set-Up}

Two-chamber MECs were constructed using two polycarbonate cubes with cylindrical chambers ( $3 \mathrm{~cm}$ inner diameter, $4 \mathrm{~cm}$ length). The polycarbonate cubes were separated by an AEM (Neosepta AMX, ASTOM, Tokyo, Japan). The anode chamber contained a graphite fiber brush (Mill-ROSE Company, Mentor, OH, USA) as the electrode, which was preheated to $450{ }^{\circ} \mathrm{C}$ for $30 \mathrm{~min}$. Two types of cathodes, a disk-type cathode and a wire-type cathode, were fabricated. The disk-type cathode (loading of $0.5 \mathrm{mg} \mathrm{Pt} / \mathrm{cm}^{2}$ and surface area of $7 \mathrm{~cm}^{2}$ ) was prepared from wet-proofed carbon cloth coated with a carbon black-based slurry containing the Pt catalyst (10\% Pt on Vulcan XC 71$)$ and $5 \%$ Nafion binder. The wire-type cathode (surface area $=1 \mathrm{~cm}^{2}$ ) was made of Ti wire coated with the same Pt catalyst slurry. However, the Pt loading on the Ti wire was only $20 \mu \mathrm{g} \mathrm{Pt} / \mathrm{cm}^{2}$ (Figure 1).
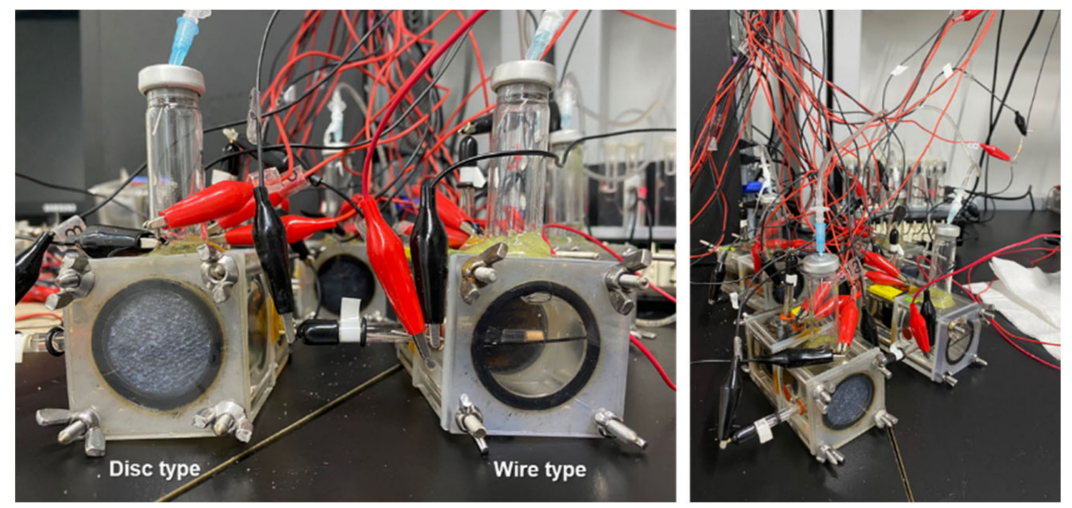

Figure 1. Images of two different cathodes and MECs.

\subsection{Reactor Operation and Measurements}

The anode was inoculated with activated sludge taken in an aeration tank from a wastewater treatment plant (Jeju city, Korea) in fed-batch mode, with an external resistance 
of $1 \mathrm{k} \Omega$. The external resistance was then switched to $10 \Omega$ and stabilized. The MECs were operated at an applied voltage of $0.9 \mathrm{~V}$ using an external power supply. The anode chamber was fed with the substrate (sodium acetate concentration ranging from 0.4 to $1.0 \mathrm{~g} / \mathrm{L}$ ) and $50 \mathrm{mM}$ phosphate buffer solution $\left(4.58 \mathrm{~g} / \mathrm{L} \mathrm{Na}_{2} \mathrm{HPO}_{4}, 2.45 \mathrm{~g} / \mathrm{L} \mathrm{NaH}_{2} \mathrm{HPO}_{4} \cdot \mathrm{H}_{2} \mathrm{O}, 0.31 \mathrm{~g} / \mathrm{L}\right.$ $\mathrm{NH}_{4} \mathrm{Cl}$, and $0.13 \mathrm{~g} / \mathrm{L} \mathrm{KCl}$ ) and supplied with $12.5 \mathrm{~mL} / \mathrm{L}$ of minerals and $5 \mathrm{~mL} / \mathrm{L}$ of vitamins [4]. The cathode chamber was filled with a $100 \mathrm{mM}$ PBS buffer solution. All the experiments were performed at $30^{\circ} \mathrm{C}$ with an external resistance of $10 \Omega$, and the system voltages were recorded using a multimeter (2700 Multimeter, Keithley Instruments Inc., Cleveland, OH, USA). A reference electrode (Ag/AgCl, RE-1B, ALS Co., Ltd, Osaka, Japan) was inserted into each chamber to monitor the electrode potentials.

The initial and final $\mathrm{pH}$ and conductivity were measured at the beginning and end of the reaction cycles using $\mathrm{pH}$ and conductivity meters (SevenMulti, Mettler-Toledo International Inc., Columbus, OH, USA), respectively. Acetate concentrations were analyzed using high-performance liquid chromatography (1200 Series, Agilent Technologies, Santa Clara, CA, USA). Gas compositions were analyzed by gas chromatography (GC 2014AT, Shimadzu, Kyoto, Japan).

\subsection{Calculation}

Coulombic efficiency (CE) was calculated in terms of electrons recovered from the supplied substrate, as given in Equation (1).

$$
\mathrm{CE}=\frac{\int_{t_{i}}^{t_{f}} I d t}{F \cdot b \cdot V \cdot \Delta c \cdot M^{-1}}
$$

where $I=V / R_{e x}$ is the current (A) calculated from the voltage across the resistor $\left(R_{\text {ex }}, 10 \Omega\right)$, $t_{i}$ and $t_{f}$ are the initial and final time for a bath cycle, respectively, $\mathrm{F}$ is Faraday's constant $\left(96,485 \mathrm{C} / \mathrm{mol} \mathrm{e}^{-}\right), \mathrm{b}$ is the number of electrons transferred per mole of substrate (i.e., $8 \mathrm{~mol}$ $\mathrm{e}^{-} / \mathrm{mol}$ acetate), $V$ is the final liquid volume in the reactor, $\Delta c$ is the substrate concentration change between $t_{i}$ and $t_{f}$, and $M$ is the molecular weight of acetate $(59 \mathrm{~g} / \mathrm{mol}$ acetate).

Cathodic hydrogen recovery $\left(r_{c a t}\right)$, is defined as the ratio of the number of moles of hydrogen recovered to that expected based on the measured current, as given in Equation (2),

$$
r_{c a t}=\frac{n_{H_{2}}}{\eta_{C E}}
$$

where $n_{H_{2}}$ is the number of moles of $\mathrm{H}_{2}$ recovered over $24 \mathrm{~h}$ and $\eta_{C E}$ is the coulombic efficiency. $\eta_{C E}$, which is based on the total coulombs recovered compared to that expected based on the initial mass of the substrate, was calculated as reported previously [8].

The energy recovery efficiency $\left(\eta_{E}\right)$ is the ratio of the energy of hydrogen produced to that added to the circuit by the power source, as shown in Equation (3),

$$
\eta_{E}=\frac{n_{H_{2}} \cdot \Delta H_{H_{2}}}{\int_{t_{=0}}^{t}\left(I_{M E C} \cdot E_{\mathrm{v}}-I_{M E C^{2}} \cdot R_{e x}\right) d t}
$$

where $\Delta H_{H_{2}}$ is the heat of combustion of hydrogen $(285.83 \mathrm{~kJ} / \mathrm{mol}), \mathrm{I}_{\mathrm{MEC}}$ is the current (A) calculated based on the voltage drop across the external resistor $\left(R_{e x}, 10 \Omega\right)$, and $E_{v}$ is the applied voltage $(\mathrm{V})$.

\section{Results and Discussion}

\subsection{Effect of Electrode Type and Substrate Concentration on the Current Produced}

The peak current densities (calculated based on cathode area) obtained with the wire and disk electrodes were $33.1 \pm 2.3 \mathrm{~A} / \mathrm{m}^{2}$ vs. $5.7 \pm 0.4 \mathrm{~A} / \mathrm{m}^{2}$ at $0.4 \mathrm{~g} / \mathrm{L}$ substrate concentration, respectively, suggesting that the former produced a 5.8 times higher current density than the latter (Figure 2). However, the volumetric peak current densities, calculated as the ratio of current generated to the anode working volume, obtained with the 
disk electrodes were 1.1-1.2 times higher under all the conditions studies, compared to those obtained with the wire electrodes, at a given applied potential of $0.9 \mathrm{~V}$ (Table 1). This apparent inconsistency is due to the reduced area of the wire electrodes, as a result of which they showed significantly higher current densities when calculated based on the cathode size. The peak current densities measured with the wire electrode at various substrate concentrations were $33.1 \pm 2.3,33.0 \pm 1.9,32.4 \pm 0.6$, and $30.4 \pm 0.5 \mathrm{~A} / \mathrm{m}^{2}$ for $0.4,0.6,0.8$, and $1.0 \mathrm{~g} / \mathrm{L}$, respectively (Figure 2). These high current densities resulted in increased overpotential, which is favorable for hydrogen generation at low substrate concentrations $[16,17]$. At the lowest substrate concentration with the wire electrodes, the current density was $10 \%$ higher than that for a higher substrate concentration. On the other hand, the MECs with disk electrodes had similar peak current densities $(5.7 \pm 0.1,5.7 \pm 0.5$, $5.1 \pm 0.5$, and $5.5 \pm 0.6 \mathrm{~A} / \mathrm{m}^{2}$ for $0.4,0.6,0.8$, and $1.0 \mathrm{~g} / \mathrm{L}$, respectively) at all substrate concentrations, but the reaction times became longer at higher substrate concentrations (Figure 2).

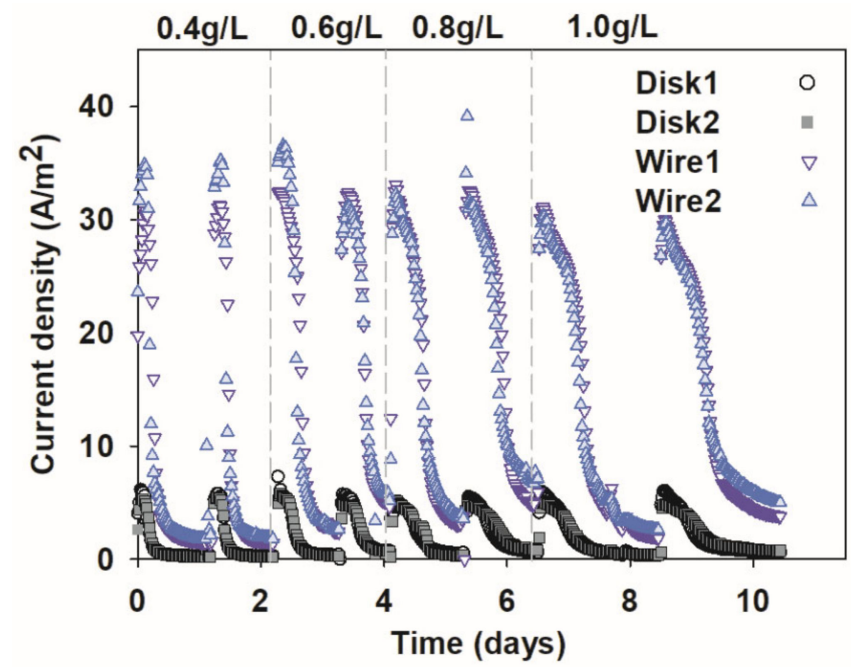

Figure 2. Current densities of MECs at different substrate concentrations.

Table 1. Volumetric peak current density at different substrate concentrations.

\begin{tabular}{ccc}
\hline Substrate Concentration $(\mathrm{g} / \mathrm{L})$ & Disk Electrode $\mathbf{( A / \mathbf { m } ^ { 3 } )}$ & Wire Electrode $\left.\mathbf{( A / \mathbf { m } ^ { 3 }}\right)$ \\
\hline 0.4 & $132.5 \pm 7.7$ & $111.6 \pm 7.6$ \\
\hline 0.6 & $131.9 \pm 12.4$ & $110.8 \pm 7.8$ \\
\hline 0.8 & $119.2 \pm 10.6$ & $108.1 \pm 2.1$ \\
\hline 1.0 & $128.4 \pm 13.4$ & $101.2 \pm 1.7$ \\
\hline
\end{tabular}

3.2. Effect of Cathode Type and Substrate Concentration on Electrode Potential, $p H$, and COD Removal

The measured anode potentials were dependent on the type of cathode and substrate concentration (Figure 3). The anode potentials in MECs equipped with wire-type cathodes were more negative $(-0.444 \mathrm{~V}$ to $-0.461 \mathrm{~V}$ vs. $\mathrm{Ag} / \mathrm{AgCl})$, compared to those with the disk-type cathode $(-0.341 \mathrm{~V}$ to $-0.331 \mathrm{~V}$ vs. $\mathrm{Ag} / \mathrm{AgCl})$, owing to the reduced cathode size in the former. Further, wire-type cathodes under conditions producing high current densities also exhibited more negative cathode potentials (from $-1.104 \mathrm{~V}$ to $-1.165 \mathrm{~V}$ vs. $\mathrm{Ag} / \mathrm{AgCl})$ compared to the disk-type cathode $(-0.874 \mathrm{~V}$ to $-1.017 \mathrm{~V}$ vs. $\mathrm{Ag} / \mathrm{AgCl})$.

Although PBS was used in the cathode chamber, the catholyte $\mathrm{pH}$ under all the conditions increased from 6.9 to 8.0, while the anolyte $\mathrm{pH}$ decreased from 7.9 to 6.8 over the course of operation of the MECs. These changes are normal, as protons are generated at the anode due to oxidation of the organic matter, whereas hydroxyl ions are generated at 
the cathode due to HER [4]. Acetate (COD), which was added as a substrate in the anode chamber in all the reactors, was completely removed.
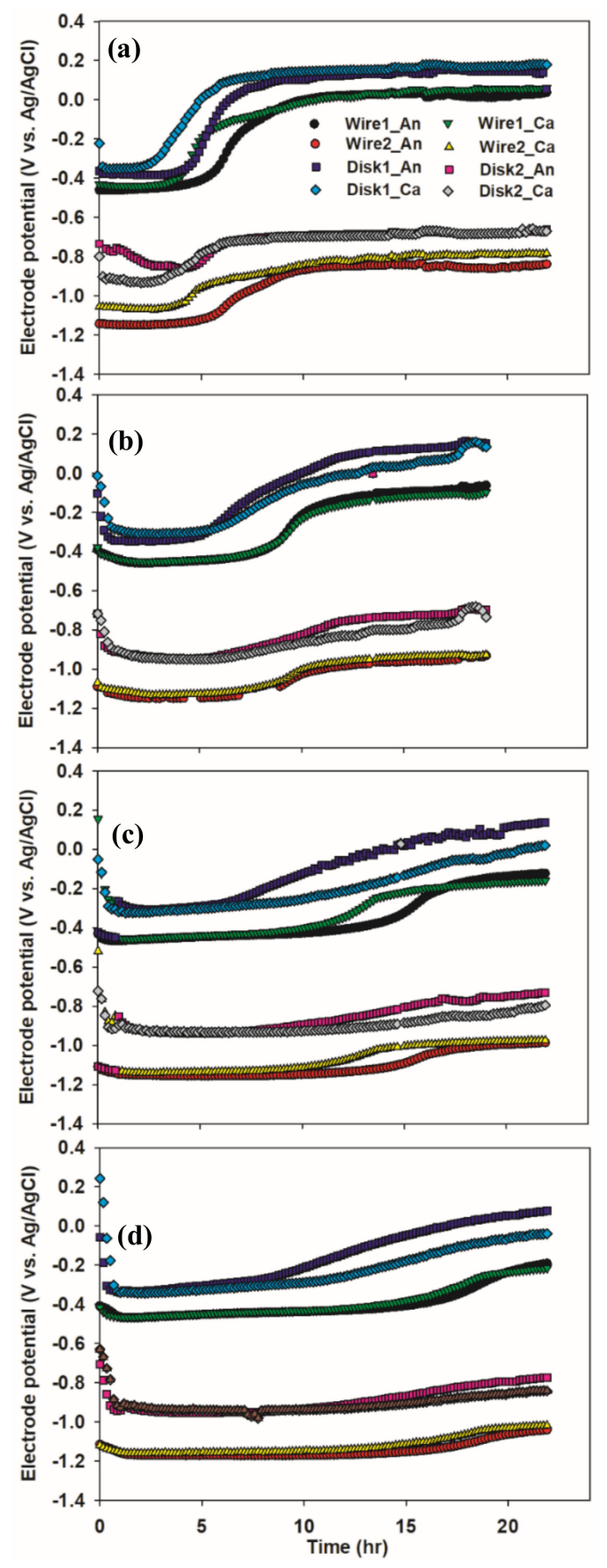

Figure 3. Anode and cathode potentials versus $\mathrm{Ag} / \mathrm{AgCl}$ reference electrodes at different substrate concentrations: (a) $0.4 \mathrm{~g} / \mathrm{L},(\mathbf{b}) 0.6 \mathrm{~g} / \mathrm{L},(\mathbf{c}) 0.8 \mathrm{~g} / \mathrm{L}$, and (d) $1.0 \mathrm{~g} / \mathrm{L}$.

\subsection{Hydrogen Production and Operational Efficiencies}

In general, the increase in the substrate concentration from 0.4 to $1.0 \mathrm{~g} / \mathrm{L}$ resulted in enhanced hydrogen production. Additionally, the wire electrodes produced a higher volume of hydrogen gas $\left(\mathrm{H}_{2}\right.$ 98.2 99.1\%) than did the disk electrodes $\left(\mathrm{H}_{2}\right.$ 97.5 98.8\%) at all substrate concentration conditions (Figure 4). For example, the gas volumes generated at $0.4 \mathrm{~g} / \mathrm{L}$ substrate concentration with the wire and disk electrodes were approximately $8.5 \pm 1.2 \mathrm{~mL}$ and $6.8 \pm 0.4 \mathrm{~mL}$, respectively. Further, an increase in the substrate concentration from 0.4 to $1.0 \mathrm{~g} / \mathrm{L}$ resulted in an increase in the hydrogen gas volumes from $8.5 \pm 1.2$ 
to $23.0 \pm 2.2 \mathrm{~mL}$ and $6.8 \pm 0.4$ to $21.8 \pm 2.2 \mathrm{~mL}$ for the wire and disk electrodes, respectively. Trace amounts of methane and carbon dioxide were also detected in the produced gas (Figure 4). In the cathode chambers equipped with the disk electrode, methane concentrations were measured to be $0.6-1.8 \%$, whereas lower amounts of methane $(0.2-1.0 \%)$ were detected in the cathode chambers with the wire electrode. On the other hand, similar amounts of carbon dioxide were detected with both the cathode types (0.6-0.8\%).

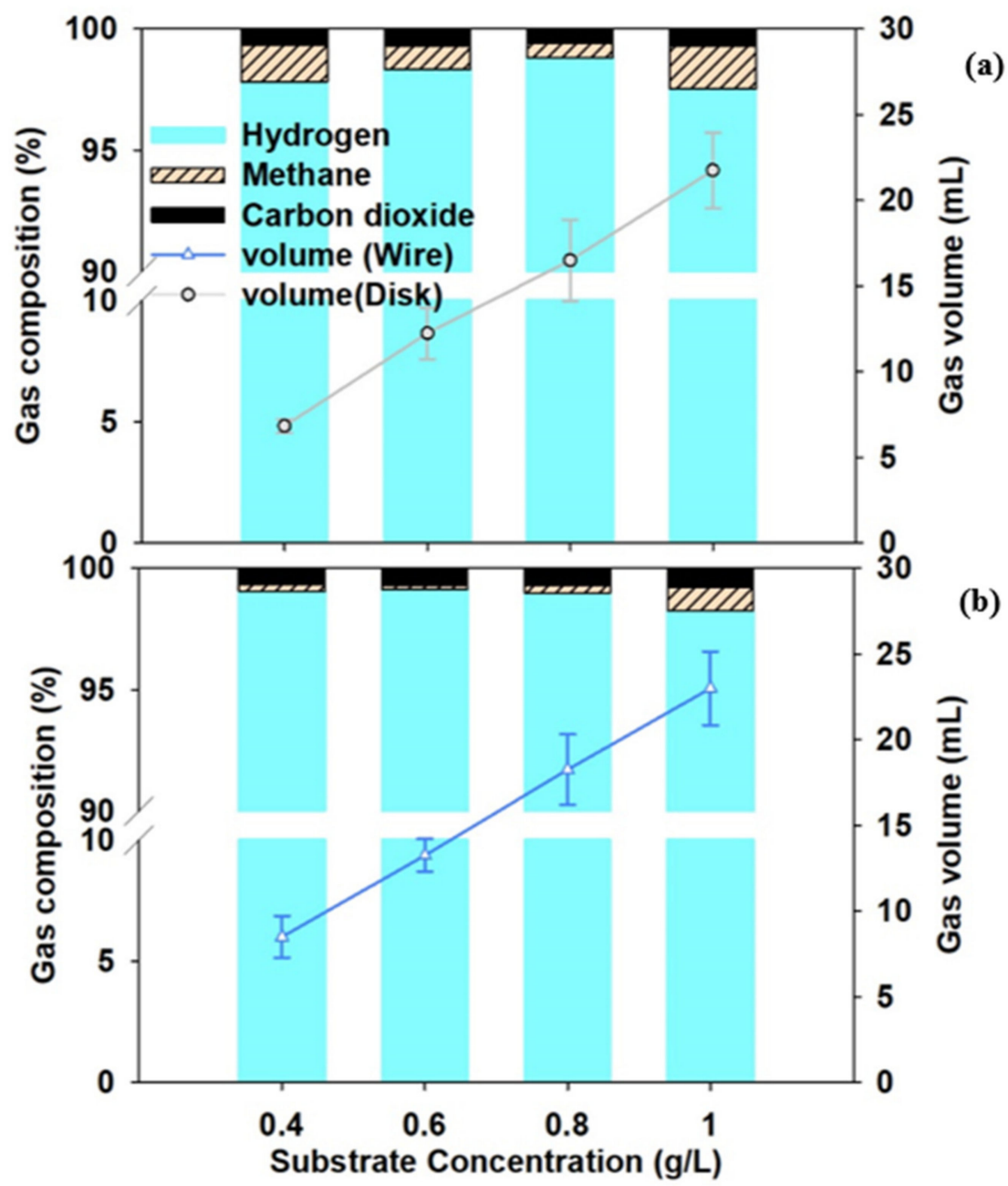

Figure 4. Total gas generation and gas compositions with different cathode types: (a) disk electrodes and $(\mathbf{b})$ wire electrodes.

Similar to the gas volumes produced, the cathodic hydrogen gas recovery $\left(r_{c a t}\right)$ values were also higher with the wire electrodes compared to the disk electrodes. For example, $r_{\text {cat }}$ values in MECs with wire electrodes were $68.7 \pm 7.1 \%, 82.5 \pm 3.9 \%, 79.8 \pm 2.8 \%$, and $79.4 \pm 3.6 \%$ for substrate concentrations of $0.4,0.6,0.8$, and $1.0 \mathrm{~g} / \mathrm{L}$, respectively. On the other hand, the disk electrodes exhibited up to $10 \%$ lower $r_{\text {cat }}$ values (Figure 5a). Consequently, energy efficiencies, that is, hydrogen recovery from the externally supplied electrical energy, were higher for the wire electrodes. The highest energy efficiency $(144.6 \pm 6.4 \%)$ was obtained with the wire electrode at $0.6 \mathrm{~g} / \mathrm{L}$ substrate concentration. The energy efficiency also increased over the course of the experiment from $133.8 \pm 17.8 \%$ to $144.6 \pm 6.4 \%$ (Figure $5 \mathrm{~b}$ ). These values were up to $20 \%$ higher than those obtained with the disk electrodes. On the other hand, coulombic efficiencies were almost similar with both the cathodes at various substrate concentrations (Figure 5a). Around 3-4\% higher coulombic efficiencies were obtained with the wire electrodes at substrate concentrations of $0.6 \mathrm{~g} / \mathrm{L}$ and $0.8 \mathrm{~g} / \mathrm{L}$. 

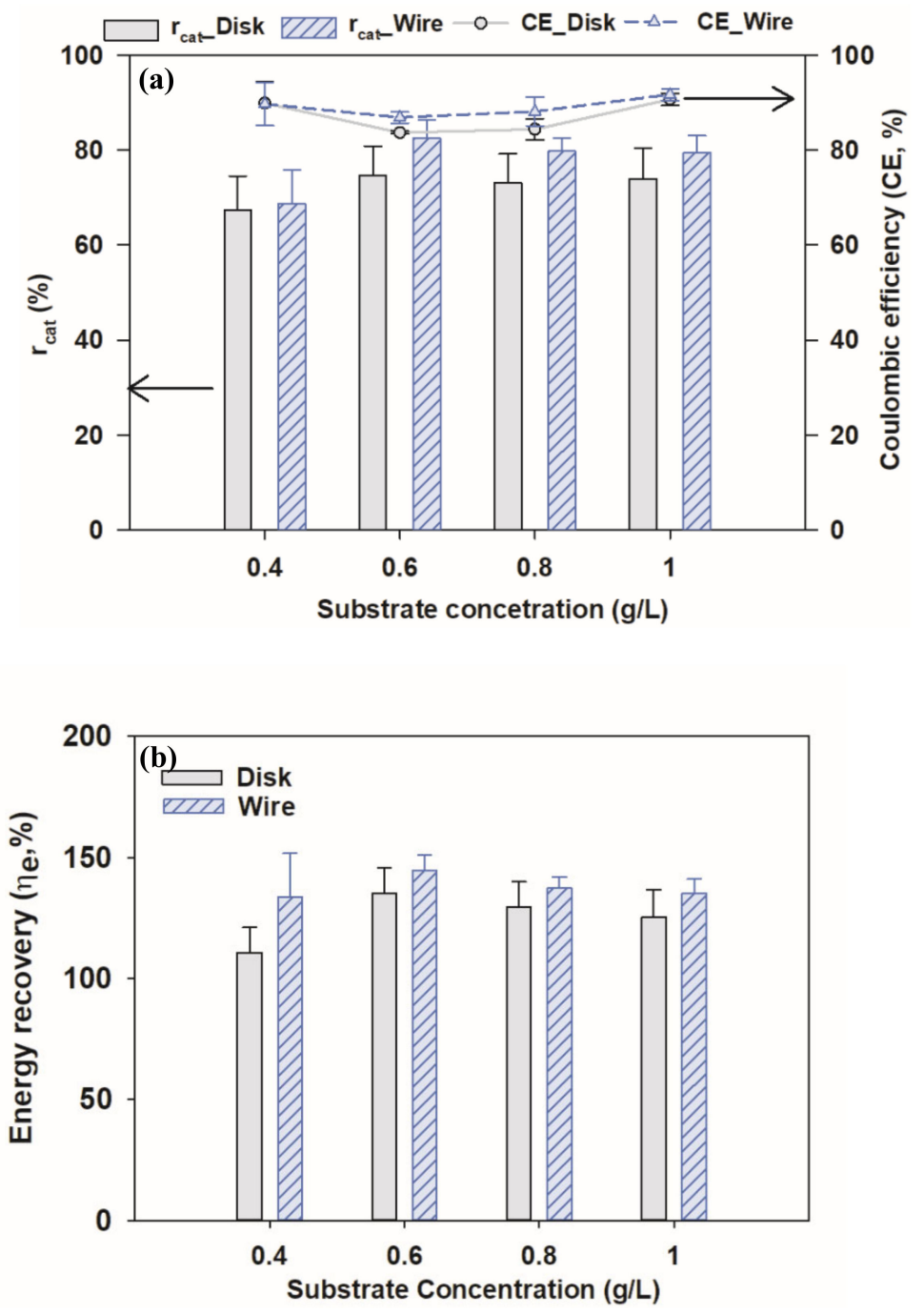

Figure 5. Efficiencies and hydrogen production yields of MECs with different cathode types at various substrate concentrations: (a) cathodic hydrogen recovery and coulombic efficiency and (b) energy recovery.

In general, high current density is required for efficient large-scale production of hydrogen by the HER [18]. However, the low organic content in domestic wastewater hinders the generation of such high current densities in MECs. One way to overcome this would be to reduce the cathode size, by which more negative potentials can be achieved, which can lead to the effective production of hydrogen at low substrate concentrations. Additionally, the mass of $\mathrm{Pt}$ catalyst in the reduced size wire cathode was 175 times lower than that in the disk electrode $(0.02 \mathrm{mg}$ vs. $3.5 \mathrm{mg})$. From the results of this study, the former is demonstrated to be efficient in MECs compared to the latter, which greatly reduces the capital cost of the MECs, since cathodes account for the highest portion [19]. Further research should be conducted to assess long-term performance of the cathode in a continuous flow system.

\section{Conclusions}

At various substrate concentrations, wire electrodes with a small surface area $\left(1 \mathrm{~cm}^{2}\right)$ and ultralow Pt catalyst loading $\left(20 \mu \mathrm{g} \mathrm{Pt} / \mathrm{cm}^{2}\right)$ produced higher volumes of hydrogen gas, in addition to showing better coulombic efficiency, cathodic hydrogen recovery, and energy efficiency compared to a disk electrode $\left(0.5 \mathrm{mg} \mathrm{Pt} / \mathrm{cm}^{2}\right.$, surface area $\left.7 \mathrm{~cm}^{2}\right)$. This difference was attributed to the reduced cathode size in the former compared to the latter, which resulted in higher current densities and hydrogen overpotentials, leading to high 
volumes of hydrogen production. Thus, a cathode with reduced size and low Pt loading is demonstrated to be suitable for use in MECs, which could greatly reduce the capital cost of MECs. This in turn would make MECs attractive for use with low strength wastewater such as domestic wastewater, because higher overpotentials obtained with small cathodes could result in the generation of more hydrogen compared to that obtained with large cathodes.

Author Contributions: Conceptualization, J.-H.H. and N.J.; methodology, E.J. and M.K.; validation, N.J. and J.-Y.N.; formal analysis, E.J. and M.K.; investigation, E.J., Y.-M.Y. and H.-C.K.; data curation, J.-Y.N., E.J. and M.K.; writing-original draft preparation, E.J. and M.K.; writing-review and editing, E.J., Y.-M.Y. and J.-Y.N.; visualization, M.K.; supervision, J.-H.H., N.J. and J.-Y.N.; project administration, N.J., H.-C.K. and J.-Y.N.; funding acquisition, N.J., H.-C.K. and J.-Y.N. All authors have read and agreed to the published version of the manuscript.

Funding: This work was conducted under the framework of the Research and Development Program of the Korea Institute of Energy Research (KIER:B7-2441) and supported by the National Research Foundation of Korea (NRF) grants funded by the Korea government (MSIT) (Nos. 2020R1C1C1009444 and 2021R1A2B5B01002656).

Institutional Review Board Statement: Not applicable.

Informed Consent Statement: Not applicable.

Data Availability Statement: Not applicable.

Conflicts of Interest: The authors declare no conflict of interest.

\section{References}

1. Lu, L.; Ren, Z.J. Microbial electrolysis cells for waste biorefinery: A state of the art review. Bioresour. Technol. 2016, 215, 254-264. [CrossRef] [PubMed]

2. Rousseau, R.; Etcheverry, L.; Roubaud, E.; Basséguy, R.; Délia, M.-L.; Bergel, A. Microbial electrolysis cell (MEC): Strengths, weaknesses and research needs from electrochemical engineering standpoint. Appl. Energy 2020, 257, 113938. [CrossRef]

3. Yang, E.; Omar Mohamed, H.; Park, S.-G.; Obaid, M.; Al-Qaradawi, S.Y.; Castaño, P.; Chon, K.; Chae, K.-J. A review on selfsustainable microbial electrolysis cells for electro-biohydrogen production via coupling with carbon-neutral renewable energy technologies. Bioresour. Technol. 2021, 320, 124363. [CrossRef] [PubMed]

4. Jwa, E.; Yun, Y.-M.; Kim, H.; Jeong, N.; Park, S.-C.; Nam, J.-Y. Domestic wastewater treatment in a tubular microbial electrolysis cell with a membrane electrode assembly. Int. J. Hydrog. Energy 2019, 44, 652-660. [CrossRef]

5. $\quad$ Liang, D.-W.; Peng, S.-K.; Lu, S.-F.; Liu, Y.-Y.; Lan, F.; Xiang, Y. Enhancement of hydrogen production in a single chamber microbial electrolysis cell through anode arrangement optimization. Bioresour. Technol. 2011, 102, 10881-10885. [CrossRef] [PubMed]

6. Nam, J.-Y.; Tokash, J.C.; Logan, B.E. Comparison of microbial electrolysis cells operated with added voltage or by setting the anode potential. Int. J. Hydrog. Energy 2011, 36, 10550-10556. [CrossRef]

7. Karthikeyan, R.; Cheng, K.Y.; Selvam, A.; Bose, A.; Wong, J.W.C. Bioelectrohydrogenesis and inhibition of methanogenic activity in microbial electrolysis cells-A review. Biotechnol. Adv. 2017, 35, 758-771. [CrossRef] [PubMed]

8. Nam, J.-Y.; Logan, B.E. Enhanced hydrogen generation using a saline catholyte in a two chamber microbial electrolysis cell. Int. J. Hydrog. Energy 2011, 36, 15105-15110. [CrossRef]

9. Jayabalan, T.; Matheswaran, M.; Naina Mohammed, S. Biohydrogen production from sugar industry effluents using nickel based electrode materials in microbial electrolysis cell. Int. J. Hydrog. Energy 2019, 44, 17381-17388. [CrossRef]

10. Call, D.F.; Merrill, M.D.; Logan, B.E. High Surface Area Stainless Steel Brushes as Cathodes in Microbial Electrolysis Cells. Environ. Sci. Technol. 2009, 43, 2179-2183. [CrossRef] [PubMed]

11. Su, M.; Wei, L.; Qiu, Z.; Wang, G.; Shen, J. Hydrogen production in single chamber microbial electrolysis cells with stainless steel fiber felt cathodes. J. Power Sources 2016, 301, 29-34. [CrossRef]

12. Kim, K.-Y.; Logan, B.E. Nickel powder blended activated carbon cathodes for hydrogen production in microbial electrolysis cells. Int. J. Hydrog. Energy 2019, 44, 13169-13174. [CrossRef]

13. Rozenfeld, S.; Teller, H.; Schechter, M.; Farber, R.; Krichevski, O.; Schechter, A.; Cahan, R. Exfoliated molybdenum di-sulfide (MoS2) electrode for hydrogen production in microbial electrolysis cell. Bioelectrochemistry 2018, 123, 201-210. [CrossRef] [PubMed]

14. Rivera, I.; Bakonyi, P.; Buitrón, G. $\mathrm{H}_{2}$ production in membraneless bioelectrochemical cells with optimized architecture: The effect of cathode surface area and electrode distance. Chemosphere 2017, 171, 379-385. [CrossRef] [PubMed]

15. Perez, D.; Lie, T.T.; Weber, C.C. Relative electrode size and organic load effects on the energy storage efficiency of microbial electrolysis cells. Bioresour. Technol. Rep. 2020, 11, 100518. [CrossRef]

16. Zhou, H.; Yu, F.; Zhu, Q.; Sun, J.; Qin, F.; Yu, L.; Chen, S.; Ren, Z. Water splitting by electrolysis at high current densities under 1.6 volts. Energy Environ. Sci. 2018, 11, 2858-2864. [CrossRef] 
17. Dickinson, E.J.F.; Wain, A.J. The Butler-Volmer equation in electrochemical theory:Origins, value, and practical application. J. Electroanal. Chem. 2020, 872, 114145. [CrossRef]

18. Xue, S.; Liu, Z.; Ma, C.; Cheng, H.-M.; Ren, W. A highly active and durable electrocatalyst for large current density hydrogen evolution reaction. Sci. Bull. 2020, 65, 123-130. [CrossRef]

19. Rozendal, R.A.; Hamelers, H.V.M.; Rabaey, K.; Keller, J.; Buisman, C.J.N. Towards practical implementation of bioelectrochemical wastewater treatment. Trends Biotechnol. 2008, 26, 450-459. [CrossRef] [PubMed] 